\title{
PENGARUH PENERAPAN MODEL PEMBELAJARAN BERBASIS PROYEK (PBP) TERHAD AP PEMAHAMAN KONSEP MATEMATIKA SISWA KELAS X PROGRAM KEAHLIAN MULTIMEDIA SMK NEGERI 3 SINGARAJA
}

\author{
I K. T. Adhiyasa, G. Suweken, I P. P. Suryawan \\ Jurusan Pendidikan Matematika \\ Universitas Pendidikan Ganesha Singaraja, Indonesia \\ e-mail : trisnaadhiyasa, gdsuweken5 @gmail.com, paseksuryawan@yahoo.com
}

\begin{abstract}
Abstrak
Penelitian ini bertujuan untuk mengetahui apakah pemahaman konsep matematika siswa yang diterapkan model Pembelajaran Berbasis Proyek (PBP) lebih baik daripada pemahaman konsep matematika siswa yang mengikuti pembelajaran konvensional. Populasi pada penelitian ini adalah seluruh siswa kelas X Program Keahlian Multimedia SMK Negeri 3 Singaraja tahun ajaran 2016/2017. Pengambilan sampel dilakukan dengan teknik cluster random sampling. Sampel dalam penelitian ini adalah siswa kelas X MM1 sebagai kelompok eksperimen dan siswa kelas X MM2 sebagai kelompok kontrol. Desain penelitian yang digunakan dalam penelitian ini adalah Post-test Only Control Group Design.Skor tes pemahaman konsep matematika siswa dianalisis dengan menggunakan uji- $t$ satu arah dengan taraf signifikansi $5 \%$. Hasil uji hipotesis menunjukkan bahwa $t_{\text {hitung }}(5,57566)>t_{\text {tabel }}$ $(1,6736)$. Akibatnya $\mathrm{H}_{0}$ ditolak dan $\mathrm{H}_{1}$ diterima, yang berarti bahwa pemahaman konsep matematika siswa yang diterapkan model Pembelajaran Berbasis Proyek (PBP) lebih baik daripada pemahaman konsep matematika siswa yang mengikuti pembelajaran konvensional. Dengan demikian, penerapan model Pembelajaran Berbasis Proyek memberikan pengaruh positif terhadap pemahaman konsep matematika siswa.
\end{abstract}

Kata kunci: Pembelajaran Berbasis Proyek (PBP), pembelajaran konvensional, pemahaman konsep

\begin{abstract}
This research was aimed to find out whether the students' understanding of mathematical concepts who learned with project based learning model is higher than students' mathematics concepts who learned with conventional learning. The population of this reasearch were all the students of grade $X$ of multimedia skills program at SMK Negeri 3 Singaraja in academic year 2016/2017. The sample was taken by using cluster random sampling technique. Sample of this research were the students in X MM1 class as the experimental group and X MM2 as control group. The design of research that used in this research is the Post-test Only Control Group Design. The score of students' understanding of mathematical concept was analyzed by using one tail t-test with $5 \%$ significance level. The result of hypothesis test showed that $t_{\text {count }}(5,57566)>t_{\text {table }}(1,6736)$. So that the null hypothesis was rejected and $H_{1}$ was accepted, which means that the students' understanding of mathematical concepts who learned with project based learning was better than students' understanding of mathematical concepts who learned with conventional learning. Thus, the implementation of project based learning model gives a postive influence on the students' understanding of mathematical concepts.
\end{abstract}

Keywords :Project Based Learning, conventional learning, students' understandingof mathematical concepts

\section{Pendahuluan}

Sekolah Menengah Kejuruan (SMK) merupakan salah satu jenjang pendidikan menengah di Indonesia yang mempersiapkan lulusannya untuk siap bekerja secara mandiri dan kompeten dalam bidang tertentu. Untuk memenuhi kompetensi lulusan tersebut, melalui Permendikbud No. 70 Tahun 2013 tentang Kerangka Dasar dan Struktur Kurikulum Sekolah Menengah Kejuruan (SMK) pemerintah mengakomodasikan minat peserta didik sesuai dengan bidang keahliannya masing-masing. 
Dengan semboyan SMK BISA, diharapkan siswa-siswi SMK mampu menjadi dan siap untuk bekerja mandiri, berkarya, bersaing, berbisnis, dan memajukan Indonesia. Selain itu tamatan siswa-siswi SMK nantinya juga diharapkan mampu melanjutkan pendidikannya ke tingkat Universitas dan mampu bersaing pada bidang keahliannya. Hal ini disesuaikan dengan tiga tuntutan dasar persaingan tamatan SMK yaitu lulusan yang sesuai dengan kebutuhan pasar, mampu meneruskan ke jenjang yang lebih tinggi, dan memungkinkan untuk menciptakan lapangan kerja dengan berwirausaha, tamatan SMK diharapkan dapat menghasilkan lulusan yang berkualitas.

Dalam mengembangkan pengetahuan konseptualnya, siswa dihadapkan pada penyelesaian soal atau permasalahanyang pasti akan menggunakan berbagai konsep dan saling terkait. Konsep yang digunakan dalam menyelesaikan permasalahan pada matematika bisa merupakan konsep baru melalui pengalaman belajarnya di kelas ataupun menggunakan konsep yang telah dipelajari sebelumnya. Dengan demikian, guru dalam pembelajarannya di kelas harus mampu merancang kegiatan pembelajaran yang dapat membuat konsep itu dipahami serta dikuasai oleh siswa dengan baik dan benar. Jadi dapat dikatakan bahwa pemahaman konsep merupakan salah satu bagian yang paling penting dalam pembelajaran matematika. Dengan perencanaan danproses kegiatan pembelajaran matematika yang baik tentunya akan mampu membuat siswa memahami konsep-konsep yang telah diajarkan serta tujuan dari pembelajaran matematika itu sendiri akan dapat terwujud.

Namun perencanaan dan kegiatan pembelajaran yang baik nampaknya belum bisa membuat hasil pembelajaran matematika di kelas sesuai dengan harapan yang ada. Pada jawaban siswaterlihat masih banyak terdapat kesalahan-kesalahan yang dibuat dalam memahami masalah, mengaplikasikan konsep serta penggunaan rumus. Selanjutnya, salah satu masalah yang menyebabkan masih rendahnya pemahaman konsep matematika siswa dikarenakan proses pembelajaran siswa SMK terbagi menjadi dua yaitu proses pembelajaran di bengkel dan proses pembelajaran teori di kelas yang membedakan dengan kegiatan pembelajaran pada Sekolah Menengah lainnya. Hal inilah yang dirasa menyebabkan kurangnya kemampuan siswa dalam mengingat serta memahami konsep di kelas teori. Selain dikarenakan fokus pembelajaran siswa yang terbagi menjadi dua, pelajaran di kelas teori sesungguhnya sangatlah berbeda dengan pelajaran di kelas bengkel. Pelajaran di kelas bengkel akan terasa lebih mudah diterima siswa mengingat segala sesuatu yang dikerjakan dan terjadi dalam proses pembelajaran sesuai dengan minat dan bakat mereka. Berbeda halnya dengan pelajaran di kelas teori yang menekankan dalam mengikuti mata pelajaran wajib ajar seperti matematika, kimia, bahasa dll. Untuk itu diperlukan alternatif pembelajaran yang dapat mengatasi permasalahan yang telah disampaikan diatas. Salah satu alternatif pembelajarannya adalah dengan menggunakan model pembelajaran yang dapat melibatkan siswa langsung kedalam kegiatannya di sekolah sekaligus dapat mengaitkan aktivitas siswabaik di bengkel maupun di kelas. Model pembelajaran yang diduga dapat menggabungkan kegiatan siswa di bengkel dan pelajaran di kelas teori adalah Model Pembelajaran Berbasis Proyek (PBP).

Pembelajaran Berbasis Proyek (PBP) adalah sebuah model pembelajaran inovatif, yang menekankan belajar kontekstual melalui kegiatan-kegiatan yang kompleks (Waras, 2008). Menurut Semiawan (1997), PBP bertujuan untuk mendapatkan pengetahuan yang diperoleh warga belajar dan memungkinkan pula warga belajar memperluas wawasan pengetahuannya dari suatu mata pelajaran tertentu. Hal inilah yang dapat menjadi jembatan penghubung antara pengetahuan yang didapatkan siswa SMK di bengkel dengan pengetahuan di kelas teori sehingga pada akhirnya siswa dapat menciptakan suatu karya (proyek) yang menghubungkan ilmu bidang/ jurusan yang diminatinya dengan ilmu pelajaran matematika. Proyek tersebut nantinya akan siswa gunakan dalam proses pembelajaran, sehingga proses penguasaan dan pemahaman konsep akan lebih mudah diterima oleh mereka.

Menurut Buck Institute of Educations Model (dalam Suarni, 2014) PBP adalah model pembelajaran yang berfokus pada konsep-konsep dan prinsip-prinsip utama dari suatu 
disiplin, melibatkan siswa dalam kegiatan pemecahan masalah dan tugas-tugas bermakna lainnya, memberi peluang siswa bekerja secara otonom, mengkonstruksi pelajaran mereka sendiri, dan puncaknya menghasilkan produk karya siswa bernilai dan realistik. Berbeda dengan model pembelajaran konvensional yang umumnya bercirikan praktek kelas yang berdurasi pendek, terisolir, dan aktivitas pembelajaran berpusat pada guru, model PBP menekankan kegiatan belajar yang relatif berdurasi panjang, holistik, terorganisasi, berpusat pada siswa dan terintegrasi dengan praktek serta isu-isu dunia nyata.

Fase-fase pelaksanaan PBP yang bersumber dari Materi Implementasi Kurikulum 2013 yaitu, (1) Penentuan PertanyaanMendasar, (2) Mendesain Perencanaan Proyek, (3) Menyusun Jadwal, (4) Memonitor peserta didik dan kemajuan proyek, (5) Menguji Hasil, (6) Mengevaluasi Pengalaman(Wisma, 2014). Fase (1) merupakan penentuan pertanyaan mendasar, guru memberikan pertanyaan berupa permasalahan nyata yang didapat dalam kehidupan siswa dan bersifat ill-defined problem sehingga siswa menjadi lebih termotivasi untuk melakukan suatu aktivitas atau kerja proyek. Pertanyaan inilah yang bermuara pada penugasan proyek peserta didik, dari pertanyaan ini siswa akan merasa tertantang dan mengetahui apa yang harus dijawab dalam pembelajaran proyek tersebut.Pada tahap ini PBP berperan sebagai alat dalam mengonstruksi ulang pemahaman konsep/ ide-ide siswa melalui pembuatan suatu proyek. Sehingga siswa nantinya akan memahami dan menyatakan kembali konsep yang mereka dapatkan di kelas serta mengaplikasikannya dalam bentuk unjuk kerja proyek.

Pada fase (2) dan fase (3), siswa diajak untuk mendesain perencanaan serta menyusun jadwal untuk membuat proyek tersebut. Proses mendesain ini melatih siswa untuk mampu merencanakan penyelesaian atas masalah yang diberikan, sehingga dalam proses ini siswa dituntut untuk memahami dan menyatakan pemahaman mereka ke dalam suatu karya berbentuk proyek. Selain itu, proses perencanaan penyelesaian proyek juga ditekankan agar seluruh siswa mau dan mampu mempertanggungjawabkan tugas yang diberikan kepada mereka. Pada tahap ini keahlian siswa dalam mengelola dirinya masingmasing dapat dilatih serta ditingkatkan sehingga otonomi siswa lebih diutamakan.

Fase (4) merupakan proses monitoring perkembangan proyek oleh guru. Pada fase ini siswa dituntut sudah mampu memahami permasalahan yang diberikan dan menerapkan perencanaan yang telah dibuat ke dalam suatu proyek. Ketika proyek itu dibuat, keterampilan serta pemahaman konsep-konsep ilmu matematika yang telah siswa pelajari sebelumnya sangat dibutuhkan.Untuk memperdalam proses pemahaman konsep, guru membimbing siswa untuk memberikan sebuah contoh permasalahan pada proyek dan mengembangkannya agar dapat diaplikasikan ke dalam penyelesaian permasalahan seharihari. Selanjutnya fase pengujian hasil proyek dilakukanoleh siswa dengan menjelaskan konsepmatematika yang telah mereka pahami melalui kegiatan unjuk kerja atau presentasi proyek. Selain itu, siswa mampu menghargai pendapat teman dengan adanya berbagai masalah serta penyelesaian yang bervariasi dari masing-masing kelompok. Dengan kegiatan presentasi proyek ini, siswa dilatih untuk mampu memahami serta mengungkapkan pemahaman konsep matematikanya dengan cara mereka sendiri. Selain itu, pada akhirnya akan membuat siswa merasa menemukan sendiri konsep - konsep yang sedang mereka pelajari.

Fase terakhir merupakan fase pembimbingan peserta didik secara berkelompok untuk melakukan refleksi terhadap aktivitas dan hasil proyek yang sudah dijalankan. Hal-hal yang direfleksi adalah kesulitan-kesulitan yang dialami dan cara mengatasinya serta perasaan yang dirasakan pada saat menemukan solusi dari masalah yang dihadapi. Selanjutnya kelompok lain diminta untuk menanggapi hasil proyek kelompok penyaji.Secara tidak langsung terjadi proses pemahaman konsep yang menuntut kelompok siswa untuk bisa memahami sekaligus membuat solusi atas permasalahan yang diberikan. Berdasarkan fasefase pembelajaran dalam model PBP diatas serta keterkaitannya terhadap indikator kemampuan pemahaman konsep siswa, terlihat bahwa dengan menerapkan model PBP di kelas diduga mampu meningkatkan pemahaman konsep siswa terutama dalam pembelajaran matematika. 
Hal tersebut diatas juga didukung oleh hasil penelitian sebelumnya oleh Wisma (2014) menunjukkan bahwa kemampuan pemecahan masalah matematika siswa kelas X TIK SMKyang diajarkan dengan model PBP lebih baik dibandingkan dengan siswa yang diajarkan dengan model pembelajaran konvensional.Dalam penelitiannya, Wisma meminta siswa untuk membuat suatu proyek berupa Lembar Kerja Proyek (LKP). Proyek tersebut berisikan laporan dari masing-masing kelompok siswa terhadap pembelajaran yang telah mereka terima sebelumnya. Teknik dalam pembuatan lapoan disusun oleh guru sedemikian hingga siswa mampu memahami serta memecahkan masalah sesuai dengan pemahamannya. Selanjutnya, penelitian yang dilakukan oleh Hudson Jackson (2102) menunjukkan adanya pengaruh yang positif dalam memahami konsep Desain Pemesinan (Geotechnical Engineering Design and Reinforced Concrete Design) dengan memanfaatkan model PBP dan studi kasus. Dalam penelitiannya, Hudson dkk menerapkan model PBP ini untuk mempraktekan secara langsung ilmu-ilmu yang didapat oleh siswa ke dalam suatu proyek berupa pemecahan kasus-kasus yang telah diberikan. Pertama siswa diberikan materi di kelas kemudian diberikan suatu kasus yang berhubungan dengan materi tersebut. Selanjutnya siswa ditugaskan untuk membuat suatu perencanaan proyek dan mencari solusi atas kasus tersebut melalui pembuatan proyek. Hasil penelitian ini menyatakan bahwa dengan penggunaan model PBP yang dikaitkan dengan permasalahan dalam kehidupan sehari-hari akan membantu siswa dalam belajar secara otonom, memahami potensi dalam dirinya, dan memperoleh pengalaman belajar. Berdasarkan hasil penelitian serta didukung oleh teori-teori dari beberapa ahli, model PBP diduga mampu menjadi jawaban atas permasalahan yang dialami oleh siswa-siswi SMK dewasa ini.

Bertolak dari paparan yang telah diuraikan diatas, rumusan masalah yang diajukan dalam penelitian ini adalah apakah pemahaman konsep matematika siswa kelas X Program Keahlian Mulltimedia SMK Negeri 3 Singaraja yang dibelajarkan dengan model Pembelajaran Berbasis Proyek lebih baik daripada pemahaman konsep matematika siswa yang dibelajarkan dengan pembelajaran konvensional.

\section{Metode}

Jenis penelitian ini adalah penelitian eksperimen dalam kategori penelitian eksperimen semu (quasi experiment).Populasi dalam penelitian ini adalah seluruh siswa Kelas $X$ Program Keahlian Multimedia SMK Negeri 3 Singaraja semester genap tahun ajaran 2016/2017 sebanyak 83 orang siswa. Dalam penelitian ini penentuan sampel dilakukan dengan menggunakan teknik cluster random sampling. Hal ini dikarenakan rumpun-rumpun yang merupakan kelompok individu itu yang tersedia sebagai unit-unit populasi, sehingga yang mendapatkan peluang yang sama untuk menjadi sampel bukanlah siswa secara individual, melainkan siswa secara kelompok (Suryabrata, 2014).

Sebelum melakukan penelitian, sampel penelitian harus diuji terlebih dahulu kesetaraanya. Data yang digunakan dalam melakukan uji kesetaraan adalah nilai Ulangan Akhir Semester siswa Kelas X semester ganjil tahun ajaran 2016/2017. Adapun uji kesetaraan untuk kelas unggulan menggunakan uji ANAVA satu jalur yang disebut dengan uji $F$.

Berdasarkan hasil uji kesetaraan, didapatkan nilai $F_{\text {hitung }}=3,047$ untuk taraf signifikansi $5 \%, \mathrm{~F}_{\text {tabel }}=3,111$, maka terima $\mathrm{H}_{0}$, sehingga dapat ditarik kesimpulan bahwa sampel dapat dikatakan memiliki rata-rata karakteristik yang setara.

Selanjutnya akan diambil dua kelas secara random sebagai sampel dan dari dua kelas tersebut akan dirandom kembali untuk menentukan kelas kontrol dan kelas eksperimen. Dari pengundian, diperoleh kelas $X$ Multimedia 1 sebagai kelas eksperimen dan kelas $X$ Multimedia 2 sebagai kelas kontrol.

Variabel bebas dalam penelitian ini adalah model pembelajaran berbasis proyek (PBP) yang akan diterapkan pada kelas eksperimen dan pembelajaran konvensional akan diterapkan pada kelas kontrol. Variabel terikat dalam penelitian ini adalah pemahaman konsep matematika siswa. 
Rancangan penelitian yang digunakan adalah Post Test Only Control Group Design. Data pemahaman konsep matematika dalam penelitian ini hanya diambil dari skor tes akhir pada kelas eksperimen maupun kelas kontrol. Desain penelitian yang dilakukan dapat dilihat pada Tabel 1 berikut.

Tabel 1 Desain Penelitian

\begin{tabular}{ccc}
\hline Kelompok & Perlakuan & Post Test \\
\hline $\mathrm{E}$ & $\mathrm{T}_{1}$ & $\mathrm{Y}_{1}$ \\
\hline $\mathrm{K}$ & $\mathrm{T}_{2}$ & $\mathrm{Y}_{2}$ \\
\hline & \multicolumn{2}{c}{ Sumber: Sugiyono (2012) }
\end{tabular}

Data yang dikumpulkan pada penelitian ini adalah berupa skor tes pemahaman konsep matematika siswa, yang dikumpulkan melalui tes pemahaman konsep matematika.indikator pemahaman konsep yang digunakan dalam penelitian ini adalah indikator yang dikembangkan oleh NCTM (2000) yaitu: (1) Describe concepts in their own words (menyatakan konsep dalam kata-kata sendiri); (2) Identify or give examples and nonexamples of concepts (mengidentifikasi atau memberi contoh atau bukan contoh dari konsep); (3) Use concepts correctly in a variety of situations (mengaplikasikan/menggunakan konsep dengan benar dalam berbagai situasi). Indikator ini yang dijadikan pedoman dalam penyusunan rubrik penskoran tes pemahaman konsep Matematika siswa.

Instrumen penelitian sebelum diberikan kepada siswa yang menjadi sampel penelitian, akan dilakukan beberapa uji untuk mendapatkan tes yang baik. Setelah instrumen penelitian disusun, pertama akan dilakukan adalah uji validitas dan uji reliabelitas untuk mengetahui validitas isi instrument. Untuk menghitung validitas butir tes digunakan rumus korelasi Product Moment dan untuk menentukan reliabilitas tes digunakan formula Alpha Cronbach.

Uji coba instrumen penelitian dilakukan di kelas XI MM3 SMK Negeri 3 Singaraja. Berdasarkan hasil penghitungan validitas tes diperoleh bahwa dari 7 soal yang diujicobakan ternyata semua merupakan soal yang valid. Ketujuh soal tersebut kemudian diuji reliabelitasnya dan diperoleh bahwa reliabelitas tes tersebut berada dalam katagori tinggi. Selanjutnya sampel akan diberikan uji post-test untuk mencari skor dari tes pemahaman konsep siswa.

Data hasil penelitian dianalisis secara bertahap, Tahapan-tahapan tersebut adalah analisis data, uji prasyarat dan uji hipotesis. Uji prasyarat yang dilakukan adalah uji normalitas sebaran data dan uji homogenitas varians. Untuk menguji normalitas sebaran skor pemahaman konsep matematika digunakan uji Kolmogorov Smirnov. Kriteria pengajuan data berdistribusi normal jika $D_{\text {hitung }}<D_{\text {tabel }}$ dengan taraf signifikasi $5 \%$.

Uji Levene digunakan untuk melihat apakah datayang digunakan memiliki varians yang homogen. Dengan kriteria pengujian jika nilai $W \geq F_{\alpha(n 1-1, n 2-1)}$ sampel tidak homogen dan jika $W<F_{\alpha(n 1-1, n 2-1)}$ sampel homogen. Pengujian ini dilakukan pada taraf signifikasi $5 \%$ dengan derajat kebebasan untuk pembilang k-1 dan derajat kebebasan untuk penyebut $N-k$

Hipotesis penelitian ini adalah pemahaman konsep matematika siswa kelas X Program Keahlian Multimedia SMK Negeri 3 Singaraja yang mengikuti pembelajaran dengan menggunakan model Pembelajaran Berbasis Masalah lebih baik daripada pemahaman konsep matematika siswa yang mengikutipembelajaran konvensional. hipotesis.

Uji-tsatu ekor (ekor kanan) dengan taraf signifikan $5 \%$ t-test, digunakan untuk menguji

\section{Hasil Penelitian}

Berdasarkan hasil perhitungan, didapatkan bahwa rata-rata skor pemahaman konsepmatematika siswa pada kelompok eksperimen lebih tinggi daripada rata-rata skor pemahaman konsep matematika siswa kelompok kontrol.Hal ini menggambarkan bahwa 
pemahaman konsep matematika siswa yang dibelajarkan dengan model Pembelajaran Berbasis Proyek lebih baik dari pemahaman konsep matematika siswa yang dibelajarkan dengan model konvensional dilihat dari skor rata-rata yang mewakili masing-masing kelompok. Jika dilihat dari standar deviasi yang dihasilkan cukup kecil ini berartinilai rata-rata yang dihasilkan mampu merepresentasikan seluruh data yang dihasilkan atau dengan kata lain rata-rata yang didapat bukan dari data yang berkelompok terlalu besar dan terlalu kecil(jauh dari rata-rata).

Untuk mengetahui apakah terdapat perbedaan yang signifikan antara pemahaman konsep matematika siswa kelas eksperimen dan kelas kontrol, maka perlu dilakukan pengujian terhadap $\mathrm{H}_{0}$. Sebelum uji hipotesis dilakukan, terlebih dahulu dilakukan pengujian terhadap normalitas dan homogenitas varians skor pemahaman konsep matematika.

Berdasarkan hasil perhitungan, didaptkan bahwadata pemahaman konsep matematika berdistribusi normal dan homogen.

Hasil uji normalitas dan uji homogenitas memperlihatkan bahwa data dari kelompok eksperimen dan kontrol berdistribusi normal dan homogen. Karena data dari kedua kelompok sampel berdistribusi normal dan homogen maka pengujian hipotesis dapat dilakukan dengan menggunakan $\mathrm{Uji}-t$ satu ekor untuk melihat ada tidaknya perbedaan pemahaman konsep matematika siswa yang mengikuti pembelajaran berbasis proyek dan pemahaman konsep matematika yang mengikuti pembelajaran konvensional.

Rangkuman hasil pengujian data pemahaman konsep matematika siswa dengan menggunakan Uji-t disajikan pada Tabel 2 berikut.

Tabel 2. Rangkuman Hasil Analisis Uji-t Data Pemahaman Konsep Matematika Siswa

\begin{tabular}{ccc}
\hline Kelompok & Eksperimen & Kontrol \\
\hline $\mathrm{N}$ & 28 & 28 \\
\hline $\bar{X}$ & 23,607 & 18,25 \\
\hline$s^{2}$ & 10,025 & 15,824 \\
\hline$S D$ & 3,166 & 3,977 \\
\hline$s_{\text {gab }}$ & \multicolumn{2}{c}{12,924} \\
\hline$t_{\text {hitung }}$ & \multicolumn{2}{c}{5,5755} \\
\hline$t_{\text {tabel }}$ & \multicolumn{2}{c}{1,6736} \\
\hline
\end{tabular}

Berdasarkan hasil analisis data pada Tabel 2 diperoleh bahwa nilai $\quad t_{\text {hitung }}>t_{\text {tabel }}$ $(5,5755>1,6736)$. Dengan demikian $H_{0}$ ditolak. Sehingga dapat disimpulkan bahwa pemahaman konsep Matematika siswa kelas X Program Keahlian Multimedia SMK Negeri 3 Singarajayang mengikuti pembelajaran dengan menggunakan model Pembelajaran Berbasis Proyek lebih baik daripadapemahaman konsep Matematika siswa yang mengikuti pembelajaran konvensional.

Penerapan model Pembelajaran Berbasis Proyek memfasilitasi siswa untuk mengonstruksi pengetahuan siswa dengan membuat siswa mengenal permasalahanpermasalahan kontekstual yang nantinya bisa terjadi pada kehidupan nyata. Hal ini disebabkan karena Pembelajaran Berbasis Proyek dilakukan secara kolaboratif yang mampu membantu siswa secara aktif menuangkan ide-ide mereka untuk menganalisis dan menyelesaikan permasalahan yang ada tanpa ada intervensi dari pendapat orang lain sebelumnya. Ide-ide tersebut dapat mereka tuangkan dalam proses investigasi (seperti penemuan masalah, desain proyek, pengambilan keputusan, penentuan jadwal, menggunakan bermacam-macam keterampilan serta mencari sendiri cara penyelesaian masalah) kemudian menyajikan hasil karya atau bentuk penyelesaian yang mereka temukan dalam bentuk proyek. Proyek yang dibuat dapat berupa penerapan konsep matematika yang dikemas dalam sebuah video pembelajaran berisi masalah kontekstual. Hal ini akan membuat siswa memiliki motivasi untuk menyelesaikan permasalahan tersebut karena permasalahan tersebut merupakan permasalahan yang bisa benar terjadi dikehidupan nyata. 
Jurnal Pendidikan dan Pembelajaran Matematika Indonesia

Vol. 7 No. 1, Tahun 2018

e-ISSN : 2615-7454

Kedua poin tersebut memiliki pengaruh dalam meningkatkan pemahaman konsep matematika siswa.

Aktivitas siswa dalam penerapan model Pembelajaran Berbasis Proyek terbukti memiliki pengaruh yang lebih unggul terhadap pemahaman konsep matematika siswa dibandingkan dengan model pembelajaran kooperatif. Hal ini dapat dilihat melalui enam langkah Pembelajaran Berbasis Proyek.

Fase pertama penentuan pertanyaan mendasar, pada awal pembelajaran dimulai guru memberikan sebuah pertanyaan terkait proyek yang dapat menumbuhkan rasa ingin tahu peserta didik.Pertanyaan/masalah yang diberikan berupa pertanyaan yang nyata yang didapat dalam kehidupan siswa dan bersifat ill-defined problem sehingga siswa menjadi lebih termotivasi untuk melakukan suatu aktivitas atau kerja proyek. Pada tahap inilah PBP berperan sebagai alat dalam mengonstruksi ulang pemahaman konsep/ ide-ide siswa melalui pembuatan suatu proyek. Sehingga siswa nantinya akan memahami dan menyatakan kembali konsep yang mereka dapatkan di kelas serta mengaplikasikannya dalam bentuk unjuk kerja proyek. Waras(2008) juga menyatakan pembelajaran berbasis proyek melibatkan tantangan-tantangan kehidupan nyata, berfokus pada pertanyaan atau masalah otentik (bukan simulatif), dan pemecahannya berpotensi untuk diterapkan di lapangan yang sesungguhnya.

Pada fase kedua dan fase ketiga merupakan proses mendesain seperti apa perencanaan penyelesaian proyek dan jadwal yang diperlukan dalam menyelesaiakan proyek.Setelah semua peserta didik paham pada permasalahan yang diberikan, kemudian mereka akan menyelesaikan permasalahan tersebut dalam bentuk suatu proyek yang telah mereka sepakati dalam kelompok masing-masing. Proyek yang dibuat merupakan suatu media tertentu yang mampu mempermudah siswa dalam memahami pelajaran yang telah mereka dapatkan di kelas. Proyek tersebut dapat berupa suatu konsep ilmu dan atau media pembelajaran. Selanjutnya kelompok siswa diminta untuk membuat dan menyepakati jadwal serta aturan dalam pembuatan proyek tersebut. Peraturan dalam proses pembuatan proyek bertujuan untuk mengawasi sekaligus melatih tanggung jawab siswa terhadap tugas yang diberikan. Peraturan tersebut memuat sanksi-sanksi yang dapat mengikat siswa di dalam proses pembuatan proyek tersebut.

Fase keempat merupakan inti dari pembelajaran berbasis proyek dalam meningkatkan pemahaman konsep matematika siswa. Pada fase ini, fokus pemahaman konsep siswa terletak pada kemajuan serta perkembangan proyek yang telah siswa kerjakan. Sebelumnya kelompok siswa telah mendesain perencanaan proyek yang akan mereka buat dan telah disepakati bersama guru. Selanjutnya, siswa akan membuat proyek tersebut di sekolah maupun di tempat-tempat yang dapat mempermudah mereka dalam menyelesaikan proyek.Selanjutnya, untuk memperdalam proses pemahaman konsep bagi siswa, guru membimbing siswa untuk mengembangkan proyek tersebut agar dapat diaplikasikan ke dalam permasalahan sehari-hari. Dengan cara ini proses pemahaman konsep pada siswa akan berjalan secara baik sesuai dengan indikatornya dalam NCTM (2000).

Selain pembuatan proyek, proses pemahaman konsep matematika siswa dikuatkan dengan pengerjaan Lembar Kerja Proyek (LKP) yang dikerjakan secara berkelompok dengan arahan guru. Lembar Kerja Proyek dikemas dalam bentuk soal-soal yang sesuai dengan permasalahan dalam proyek yang sedang siswa kerjakan. Hal ini mampu menjadi suatu suplemen dalam memahami serta menyatakan ulang konsep-konsep yang telah diajarkan oleh guru di kelas sehingga pengerjaan proyek yang dilakukan siswa menjadi semakin mudah untuk diselesaikan. Aktivitas siswa pada tahap ini adalah (a) terdapat masalah yang pemecahannya tidak ditentukan sebelumnya, (b) siswa merancang proses untuk mencapai hasil, (c) siswa bertanggung jawab untuk mendapatkan dan mengelola informasi yang dikumpulkan, (d) siswa melakukan evaluasi secara kontinu, (e ) siswa secara teratur melihat kembali apa yang mereka kerjakan, (f) hasil akhir berupa produk dan dievaluasi kualitasnya, dan (g) kelas memiliki atmosfer yang memberi toleransi kesalahan dan perubahan (Wisma, 2015). 
Pada fase kelima siswa melaporkan hasil kerja mereka dalam bentuk unjuk kerja dan melakukan perbaikan atas proyek mereka yang masih salah, disini terjadi proses refleksi terhadap rencana dan penyelesaian suatu permasalahan. Ketika proses unjuk kerja proyek berlangsung, siswa pada kelompok lain akan memberikan pertanyaan ataupun masukan dan akan ditanggapi oleh kelompok penyaji. Setelah menerima jawaban dari kelompok penyaji, penanya beserta siswa lainnya akan diharapkan mampu memahami proyek atas permasalahan serta solusi yang telah disampaikan. Dalam fase ini, tugas guru sebagai fasilitator sekaligus pembimbing berperan penting agar pertanyaan serta tanggapan dapat benar-benar dipahami oleh siswa dan sesuai dengan tujuan pembelajaran. Melalui unjuk kerja atau presentasi masing-masing kelompok di depan kelas, siswa dilatih untuk menghargai pendapat teman dengan adanya berbagai masalah serta penyelesaian yang bervariasi dari masing-masing kelompok. Melalui proses ini, pada akhirnya akan membuat siswa merasa menemukan sendiri konsep - konsep yang sedang mereka pelajari.

Fase terakhir merupakan fase pembimbingan peserta didik secara berkelompok untuk melakukan refleksi terhadap aktivitas dan hasil proyek yang sudah dijalankan. Hal-hal yang direfleksi adalah kesulitan-kesulitan yang dialami dan cara mengatasinya serta perasaan yang dirasakan pada saat menemukan solusi dari masalah yang dihadapi. Selanjutnya kelompok lain diminta untuk menanggapi hasil proyek kelompok penyaji. Pada fase ini peran guru sangat penting untuk memancing siswa agar berkeinginan untuk menanggapi hasil karya kelompok penyaji. Guru harus mampu membuat situasi kelas menjadi aktif secara diskusi dan tanya jawab. Melalui proses tersebut, guru dapat mengevaluasi pemahaman siswa serta menilai siswa secara individu maupun kelompok. Selain itu proses pemahaman konsep dapat berjalan dengan baik melalui proyek yang telah dibuat oleh siswa. Proyek tersebut memuat solusi-solusi permasalahan yang telah diberikan sebelumnya dan dinyatakan ulang ke dalam sebuah karya berbentuk proyek. Secara tidak langsung terjadi proses pemahaman konsep yang menuntut kelompok siswa untuk bisa memahami sekaligus membuat solusi atas permasalahan yang diberikan.

Sejalan dengan pernyataan di atas, Wisma (2014) menyatakan bahwa penerapan model Pembelajaran Berbasis Proyek (PBP) pada hakekatnya merupakan suatu model pembelajaran yang mampu meningkatkan kemampuan pemecahan masalah siswa. Hal ini dapat dilihat dari langkah-langkah PBP yang mampu menggiring siswa untuk mencari, menggali, menemukan serta memahami konsep yang mereka dapatkan dalam pengalamannya belajar di kelas. Dalam menemukan suatu konsep pada pembelajaran, secara tidak langsung siswa akan dihadapkan dengan suatu permasalahan awal yang selanjutnya diminta untuk memahami dan merencanakan suatu penyelesaian akan masalah tersebut. Penyelesaian yang dibuat berupa suatu proyek kerja kelompok siswa. Dengan merancang pola penyelesaian proyek yang baik, siswa dilatih untuk bekerja secara aktif dan berkelompok. Hal ini mampu melatih tanggung jawab siswa dalam menyelesaikan proyek kelompok mereka. Selanjutnya, siswa diminta untuk melakukan kegiatan penyelesaian atas permasalahan yang diberikan dapat berupa jawaban lisan, kegiatan unjuk kerja maupun presentasi. Diakhir pembelajaran, siswa diajak untuk mengevaluasi hal-hal yang telah mereka dapatkan di kelas. Kegiatan ini dapat berupa tanya jawab, diskusi dan memeriksa kembali langkah-langkah penyelesaian masalah yang telah dilakukan dan disimpulkan sebelumnya. Hal ini menujukkan dengan penerapan model PBP siswa diarahkan untuk menemukan serta memahami konsep sehingga mampu menyelesaikan permasalahan yang diberikan. Melihat terlaksananya seluruh indikator pemecahan masalah dalam penerapan PBP, sehingga dapat dikatakan kemampuan pemecahan masalah siswa meningkat dengan menekankan pada pemahaman konsep materi pembelajaran.

Meskipun sudah banyak hal positif yang dikemukakan tetapi dalam pembelajarannya di kelas terdapat pula kendala dari pelaksanaan pembelajaran dengan penerapan model Pembelajaran Berbasis Proyek. Hal tersebut diantaranya, (1) tugas proyek yang diberikan kepada siswa merupakan tugas yang dikerjakan selama beberapa pertemuan pelajaran. Hal ini berdasarkan hasil kesepakatan siswa bersama guru yang menentukan proyek yang dibuat berupa konsep ilmu matematika yang dikemas dalam suatu video pembelajaran. 
Untuk mengatasi permasalahan ini, guru selalu melakukan refleksi dan bimbingan terhadap kelompok siswa di setiap pertemuan pembelajaran. Selain untuk membantu permasalahan siswa, bimbingan ini berutujuan agar siswa benar-benar mampu dan secara baik memahami konsep yang telah mereka dapatkan sebelumnya;(2) kegiatan pembelajaran seperti kegiatan diskusi dan tanya jawab masih didominasi oleh beberapa siswa yang berkemampuan tinggi atau pandai. Untuk merefleksi pemahaman siswa terhadap proyek yang telah dibuat, pada pertemuan sebelum diadakannya unjuk kerja hasil proyek, seluruh siswa dibagikan proyek yang dibuat oleh kelompok lain dan menugaskan setiap siswa untuk membuat pertanyaan serta memberikan tanggapan akan hasil kinerja kelompok lainnya; (3) adanya perselisihan antara rekan sekelompok. Hal ini disebabkan karena beberapa siswa masih kurang disiplin dalam mengelola waktu kerjanya. Oleh karena itu guru bersama siswa membuat suatu aturan berupa sanksi yang telah disepakati oleh seluruh siswa di awal pertemuan.

Berdasarkan hasil pengujian hipotesis dan gambaran deskriptif di atas, dapat dilihat bahwa penerapan model Pembelajaran Berbasis Proyek berpengaruh terhadap pemahaman konsep matematika siswa. Dapat dikatakan, melalui penerapan model PBP dapat membuat (1) siswa mampu menyatakan ulang konsep yang telah didapatkan sesuai dengan pemahamannya sendiri (2) siswa mampu membedakan contoh dan bukan contoh, dan (3) siswa mampu mengaplikasikan konsep matematika yang didapat ke dalam suatu karya proyek dan diterapkan dalam permasalahan sehari-hari. Hasil tersebut mendukung terjadinya peningkatan pemahaman konsep matematika siswa.

\section{Simpulan dan Saran}

Berdasarkan uraian pada hasil penelitian dan pembahasan, dapat disimpulkan bahwa pemahaman konsep matematika siswa yang diterapkan dengan model Pembelajaran Berbasis Proyek lebih tinggi daripada pemahaman konsep matematika siswa yang mengikuti pembelajaran konvensional. Jadi, pembelajaran matematika dengan model Pembelajaran Berbasis Proyek memberikan pengaruh positif terhadap pemahaman konsep matematika siswa.

Berdasarkan simpulan di atas, dapat disampaikan beberapa saran bahwa bagipraktisi pendidikan khususnya guru, disarankan untuk menggunakan model Pembelajaran Berbasis Proyek sebagai salah satu alternatif strategi pembelajaran matematika terutama apabila ingin meningkatkan pemahaman konsep siswa. Hal ini berdasarkan pada hasil penelitian diatas yang memperlihatkan penerapan model PBP ini dapat membantu guru mengaitkan pembelajaran yang diterima siswa di kelas teori maupun pembelejaran di bengkel. Sehingga siswa nantinya mampu menerapkan ilmu yang mereka dapatkan ke dalam suatu unjuk kerja berupa presentasi proyek siswa. Selain itu, bagi para peneliti yang tertarik untuk melaksanakan penelitian lebih lanjut mengenai penerapan model Pembelajaran Berbasis Proyek, disarankan untuk meneliti pengaruh model ini terhadap aspek pembelajaran yang berbeda dan pada jenjang yang berbeda. Misalnya, terhadap kemampuan penalaran matematika pada siswa kelas XI Program Keahlian Teknik Gambar Bangunan. Dalam melakukan penelitian dengan menerapkan model PBP diharapkan agar memperhatikan kekurangan atau kelemahan strategi ini sebagai bahan pertimbangan untuk perbaikan dan penyempurnaan pelaksanaan penelitian selanjutnya.

\section{Daftar Pustaka}

Candiasa, I. M. 2010a. Pengujian Instrumen Penelitian Disertai Aplikasi ITEMAN dan BIGSTEPS. Singaraja : Universitas Pendidikan Ganesha.

Candiasa, I. M. 2010b. Statistik Univariat dan Bivariat Disertai Aplikasi SPSS. Singaraja: Universitas Pendidikan Ganesha.

Jackson, H., Tarhini, K., Maggi, B., Nathan, R. 2012. Improving Students Understanding of Engineering Concepts Through Project Based Learning. Journal of United States Coast Guard Academy, New London (diakses pada 19 Agustus 2016). 
Mendikbud. 2016. Peraturan Menteri Pendidikan dan Kebudayaan Nomor 20 Tahun 2016 tentang Standar Kompetensi Lulusan Pendidikan Dasar dan Menengah. Jakarta: Mendikbud RI

Mendikbud. 2016. Peraturan Menteri Pendidikan dan Kebudayaan Nomor 21 Tahun 2016 tentang Standar Isi Pendidikan Dasar dan Menengah. Jakarta: Mendikbud RI

Mendikbud. 2013. Permendikbud no 70 tahun 2013 tentang Kerangka Dasar dan Struktur Kurikulum Sekolah Menengah Kejuruan/ Madrasah Aliyah Kejuruan. Jakarta: Mendikbud RI

NCTM. 2000. Mathematics Assessment a Practical Handbook for Grades 6-8. United States of America: NCTM.

NCTM. 2000. Principles and Standards for School Mathematics. United States of America: NCTM.

Noviadewi, N P. 2016. Peningkatan Pemahaman Konsep Matematika Siswa Kelas VIII B6 SMP Negeri 4 Singaraja Tahun Ajaran 2015/2016 Melalui Penerapan Strategi PQ4R. Skripsi (tidak diterbitkan). Singaraja: Universitas Pendidikan Ganesha

Semiawan, C. 1997. Perspektif Pendidikan dan Anak Berbakat. Jakarta: Gramedia

Suarni, N M. 2014. Pengaruh Model Pembelajaran Berbasis Proyek terhadap Minat dan Hasil Belajar IPA, Siswa Kelas V Gugus 1 Kecamatan Kuta. Tesis (tidak diterbitkan). Singaraja: Program Pasca Sarjana Universitas Pendidikan Ganesha.

Sugiyono. 2012. Metode Penelitian Pendidikan. Bandung: Alfabeta.

Suryabrata, S. 2014. Metodologi Penelitian. Jakarta: Raja Grafindo Persada.

Waras, K. 2008. Project-Based Learning : Pendekatan Pembelajaran Inovatif. Makalah. Disampaikan dalam Pelatihan Penyusunan Bahan Ajar Guru SMP dan SMA Kota Tarakan, 31 Oktober s.d. 2 November 2008. Universitas Negeri Malang. Tersedia dalam http://dc262. 4shared.com /doc/etY0OFZ3/preview.html

Wisma, A A P. 2014. Pengaruh Model Project Based Learning (PJBL) terhadap Kemampuan Pemecahan Masalah Matematika Siswa Kelas X TIK SMK Negeri 3 Singaraja Tahun Pelajaran 2013/2014. Skripsi (tidak diterbitkan). Singaraja: Universitas Pendidikan Ganesha 